\title{
The environmental risk of storing vehicles over the soil
}

Automotive vehicles are a potential source of heavy metal contamination of the soil due to their lead-acid batteries and the use of metals in their structure and paint pigments. Understanding the characteristics of heavy metal soil contamination and identifying their environmental exposure provides important information for making decisions regarding remediation of contaminated soils. The objective of the present work was to evaluate metal contamination ( $\mathrm{Cd}, \mathrm{Pb}, \mathrm{Ni}$, $\mathrm{Zn}$, $\mathrm{Cu}$ e $\mathrm{Cr}$ ) in 35 soil samples (fraction $<2 \mathrm{~mm}$ ). The samples were collected from two unpaved/unsealed storage areas used by the Highway Patrol (Polícia Rodoviária Federal - PRF) for storing apprehended vehicles, one located in Araucária (AR) and one Colombo (CL), in the metropolitan region of Curitiba/PR, Brazil. Assays were performed to determine organic carbon $(\mathrm{OC})$ and $\mathrm{pH}$. For analysis of metals, the samples were prepared by acid digestion (method EPA 3050-B) and measured by ICP-OES. The results were evaluated according to Resolution CONAMA 420, geoaccumulation index (Igeo), contamination factor (CF) and Pearson correlation analysis. The textural composition of the soil at AR and CL reflect a high degree of heterogeneity and distinct chemical and physical characteristics. The AR site had a higher level of sand and a more acidic $\mathrm{pH}$ than $\mathrm{CL}$, and concentrations of the analyzed elements between prevention and investigation values according to Resolution CONAMA 420/2009. The CL site had a higher concentration of clay and OC, and a less acidic pH than AR. Only one collected point at CL had a concentration of $\mathrm{Cu}$ above the prevention value. In both $\mathrm{AR}$ and $\mathrm{CL}$, the element $\mathrm{Cd}$ was below detectability with methodology employed. The spatial distribution of the cars associated with the soil texture and the analyzed elements exhibited a random surface distribution of elements. The $\mathrm{OC}$ content, soil $\mathrm{pH}$ and texture associated with Igeo, CF and Pearson correlation suggests that both environments suffer an input of metals at different points. The input of heavy metals from stored vehicles and the possible anthropogenic impact on the soil is evident.

Keywords: Metals; Soil contamination; Vehicle depot; Trace elements.

\section{O risco ambiental de armazenar veículos sobre o solo}

\begin{abstract}
Os veículos automotores são uma fonte potencial de contaminação do solo por metais pesados ??devido às suas baterias de chumbo-ácido e ao uso de metais em sua estrutura e pigmentos de pintura. Compreender as características da contaminação do solo por metais pesados e identificar sua exposição ambiental fornece informações importantes para a tomada de decisões quanto à remediação de solos contaminados. O objetivo do presente trabalho foi avaliar a contaminação por metais ( $\mathrm{Cd}, \mathrm{Pb}, \mathrm{Ni}, \mathrm{Zn}, \mathrm{Cu}$ e $\mathrm{Cr}$ ) em 35 amostras de solo (fração<2 mm). As amostras foram coletadas em duas áreas de armazenamento não pavimentadas/não vedadas utilizadas pela Polícia Rodoviária Federal - PRF para armazenamento de veículos apreendidos, uma localizada em Araucária (AR) e outra em Colombo (CL), na região metropolitana de Curitiba/PR, Brasil. Ensaios foram realizados para determinar carbono orgânico (CO) e pH. Para análise dos metais, as amostras foram preparadas por digestão ácida (método EPA 3050-B) e medidas por ICP-OES. Os resultados foram avaliados de acordo com a Resolução CONAMA 420, índice de geoacumulação (Igeo), fator de contaminação (CF) e análise de correlação de Pearson. A composição textural do solo em $\mathrm{AR}$ e $\mathrm{CL}$ reflete um alto grau de heterogeneidade e características químicas e físicas distintas. $\mathrm{O}$ sítio de $\mathrm{AR}$ apresentou maior teor de areia e pH mais ácido que $\mathrm{CL}$, e concentrações dos elementos analisados entre os valores de prevenção e investigação conforme Resolução CONAMA 420/2009. O sítio CL apresentou maior concentração de argila e OC e pH menos ácido do que $\mathrm{AR}$. Apenas um ponto coletado no $\mathrm{CL}$ apresentou concentração de $\mathrm{Cu}$ acima do valor de prevenção. Tanto no $\mathrm{AR}$ quanto no $\mathrm{CL}$, o elemento $\mathrm{Cd}$ estava abaixo da detectabilidade com a metodologia empregada. A distribuição espacial dos carros associada à textura do solo e os elementos analisados exibiram uma distribuição superficial aleatória dos elementos. O teor de $\mathrm{CO}, \mathrm{pH}$ e textura do solo associados à correlação de Igeo, $\mathrm{CF}$ e Pearson sugere que ambos os ambientes sofrem entrada de metais em pontos diferentes. A entrada de metais pesados de veículos armazenados e o possível impacto antropogênico no solo é evidente.
\end{abstract}

Palavras-chave: Metais; Contaminação do solo; Depósito de veículos; Vestígios.

Topic: Ciências do Solo

Reviewed anonymously in the process of blind peer.

Cleyton Nascimento Makara (iD)

Universidade de São Paulo, Brasil

http://lattes.cnpq.br/7241015092201765

http://orcid.org/0000-0002-8034-2582

cleytonmakara@gmail.com

Larissa Kummer (1D)

Universidade Tecnológica Federal do Paraná, Brasil http://lattes.cnpq.br/7892203021390255

http://orcid.org/0000-0002-8282-2045

lkummer@utfpr.edu.br

Maurici Luzia Charnevski Del Monego (id

Universidade Tecnológica Federal do Paraná, Brasil

http://lattes.cnpq.br/1410424302920222

http://orcid.org/0000-0002-9093-3802

maurici@utfpr.edu.br
Received: 02/10/2020

Approved: $\mathbf{2 0 / 1 1 / 2 0 2 0}$

\section{Referencing this:}

MAKARA, C. N.; KUMMER, L.; MONEGO, M. L. C. D.. The environmental risk of storing vehicles over the soil. Revista Ibero Americana de Ciências Ambientais, v.11, n.6, p.1-12, 2020. DOI: http://doi.org/10.6008/CBPC2179-6858.2020.006.0001 


\section{INTRODUCTION}

Heavy metals are among the most dangerous of materials and they threaten environments throughout the world. They are characterized by having a long residual period, complex chemical behavior, eco-reactivity, and high visibility, toxicity and mobility, and are not degraded biologically and/or chemically. Heavy metals in the soil can be carried by rain water and contaminate groundwater via leaching, especially under acidic conditions (HONG et al., 2002; SINGH et al., 2004; DURUIBE et al., 2007; POURANG et al., 2014; PRADHAN et al., 2014; WU et al., 2014).

Heavy metals are ubiquitous in the environment, either naturally occurring or through human actions (SERRANO et al., 2005; AHMED et al., 2015; ISLAM et al., 2015). However, due to human development, the heavy metal content in the soil has increased dramatically, making it dangerous when transferred and bioconcentrated at all levels of the food chain, even at low concentrations (IKEDA et al., 2000; POURANG et al., 2014; ISLAM et al., 2015).

Among the chemical characteristics of the soil, pH plays a key role in the solubility and availability of heavy metals. In general, increasing $\mathrm{pH}$ of the soil decreases the availability of metals by means of precipitation reactions and by increasing the adsorption by variably charged colloids (SHUMAN, 1998). Organic matter present in the soil is also of great importance because it is one of the factors governing the accumulation of heavy metals (COVELO et al., 2007b, a; KASHEM et al., 2007).

Many automotive vehicles are seized for various reasons and stored improperly, being exposed to varying climatic conditions. The metals present in the structure and paint of vehicles are subjected to the processes of decomposition, and can be carried to the soil and deposited in the surface layers, which constitutes a serious risk to public health and the environment by altering the local chemical composition. These sites are also subjected to the contribution of organic and inorganic compounds from leaks of fuel, liquid in batteries, and lubricating oils.

Some of these metals, such as $\mathrm{Cu}, \mathrm{Ni}$ and $\mathrm{Zn}$, are essential nutrients for plant development, but in high concentrations they become toxic. Others, such as $\mathrm{Cd}, \mathrm{Hg}$ and $\mathrm{Pb}$, are not nutrients and are toxic (DUARTE et al., 2007; RAHMAN et al., 2014; AHMED et al., 2015; ISLAM et al., 2015).

The soil of a particular area is considered contaminated if, among other factors, the concentrations of elements or substances of environmental interest are above a certain threshold limit called the intervention value. Above this limit there is a potential risk of deleterious effects on human health, and thus immediate action in the area is required (ZEITOUNI et al., 2007).

The need to prevent soil contamination is of fundamental importance for the maintenance of its functionality, the protection of surface and ground water quality, and the prevention of harmful effects to organisms when ingested (PEREIRA et al., 2010).

The objective of the present study is to elucidate the physical and chemical attributes of the soil in two unpaved/unsealed areas used for storing vehicles seized by the Highway Patrol (Polícia Rodoviária Federal - PRF), located in Araucária (AR) and Colombo (CL), in the metropolitan region of Curitiba - PR - 
Brazil. Data for metals were assessed with regard to Resolution CONAMA 420/2009 and tested for correlation with textural characteristics of the sampling points. The findings may shed light on the environmental impacts of heavy metals in the soil of unpaved/unsealed locations used to store vehicles and, therefore, require notification of authorities.

\section{MATERIALS AND METHODS}

\section{Characteristics of the study area}

Two seized/abandoned vehicle storage/depository areas used by the Department of Highway Patrol (Departamento da Polícia Rodoviária Federal do Paraná - DPRF) located in the metropolitan region of Curitiba (Paraná, Brazil) were chosen for study. Twenty samples of surface soil were collected in an unit of DPRF from along the margins of highway BR-116 (Highway Régis Bittencourt) in the municipality of Colombo (CL) (25은 22' 31,24" S and 49 09' 5,03" W), Point 1 in Figure 1; and 15 samples of surface soil were collected in an unit of DPRF from along the margins of highway BR-476 (Highway Xisto) in the municipality of Araucária (AR) (25은 $36^{\prime} 36,76^{\prime \prime} \mathrm{S}$ and 49o 25'21,13" W), Point 2 in Figure 1. These regions are characterized by having heavy vehicle traffic and being heavily populated and industrialized.

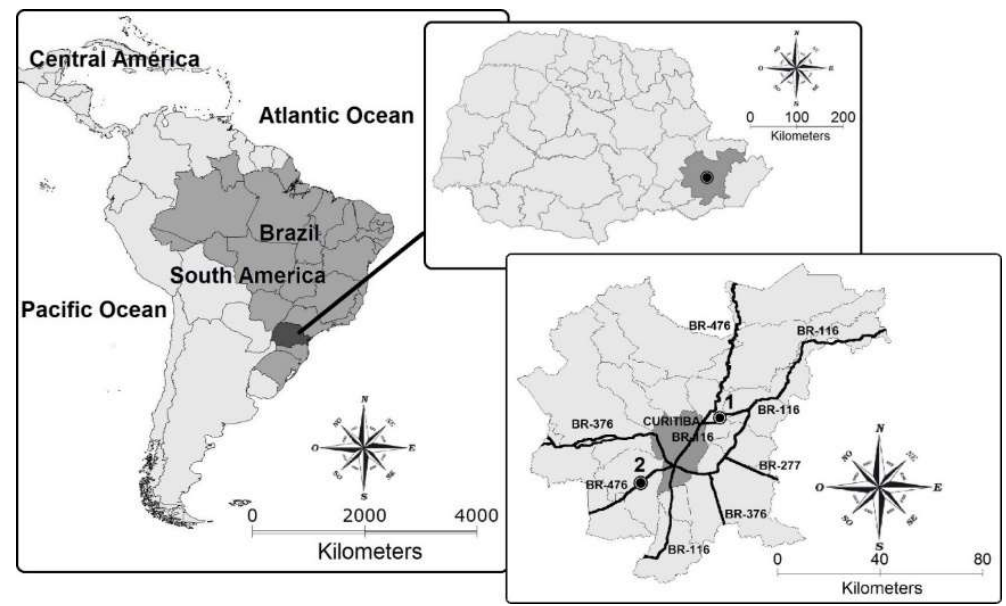

Fig. 1: Map of the study area and location of sampling points (1 - Colombo (CL), 2 - Araucaria (AR)).

\section{Sampling}

Soil samples were collected from the two study areas at points of varying distance from each other at depths of $0-20 \mathrm{~cm}$ with the aid of a Dutch-type auger. The samples were stored in plastic containers, identified, sealed and transported to the Laboratório de Análises de Solos of the Federal University of Technological - Paraná following the technical specifications of EMBRAPA (1997). Geodetic coordinates were taken for each sampling point using a Garmin model GPS76 Global Positioning System. The samples were dried and sieved through a $2 \mathrm{~mm}$ mesh sieve to obtain airdried fine earth (AFE).

\section{Solutions and reagents}

All reagents used in the digestion and assays were of analytical grade: Sodium Hydroxide $(\mathrm{NaOH})$, Calcium Chloride $\left(\mathrm{CaCl}_{2}\right)$, Potassium Chloride $(\mathrm{KCl})$, Sodium Dichromate $\left(\mathrm{Na}_{2} \mathrm{Cr}_{2} \mathrm{O}_{7}\right)$, Sulfuric Acid $\left(\mathrm{H}_{2} \mathrm{SO}_{4}\right)$, 
Hydrochloric Acid $(\mathrm{HCl})$, and Nitric Acid $\left(\mathrm{HNO}_{3}\right)$. Deionized water was ultra-pure water Milli-Q (Millipore, model Direct-Q 8).

Glassware and polyethylene bottles remained immersed in a 10\% nitric acid PA (Merck) for $48 \mathrm{~h}$ (BRANDÃO et al., 2011), and then rinsed with deionized water and dried at room temperature. Standard solutions of the elements used for calibrating the Inductively Coupled Plasma Optical Emission Spectrometer (ICP-OES) were prepared by diluting a stock solution of $1000 \mathrm{mg} \mathrm{L}^{-1}(\mathrm{Cd}, \mathrm{Pb}, \mathrm{Cu}, \mathrm{Cr}, \mathrm{Ni}$ and $\mathrm{Zn}$ ).

\section{Chemical analysis of soil}

Physical and chemical attributes were determined for AFE according to EMBRAPA (1997). The distribution of particle size was evaluated using the pipette method using dispersion with $1 \mathrm{~mol} \mathrm{~L}^{-1} \mathrm{NaOH} ; \mathrm{pH}$ of the soil was determined in $\mathrm{H}_{2} \mathrm{O}$ and $1 \mathrm{~mol} \mathrm{~L}^{-1} \mathrm{CaCl}_{2}$; exchangeable $\mathrm{Ca}^{2+}$ and $\mathrm{Mg}^{2+}$ were extracted with $1 \mathrm{~mol}$ $\mathrm{L}^{-1} \mathrm{KCl}$ and determined by complexiometry; exchangeable $\mathrm{Na}^{+}$and $\mathrm{K}^{+}$were extracted by Mehlich-1 solution and determined by flame photometry; and exchangeable $\mathrm{Al}^{3+}$ extracted with $1 \mathrm{~mol} \mathrm{~L}^{-1} \mathrm{KCl}$ and determined by titration with a solution of $0.025 \mathrm{~mol} \mathrm{~L}^{-1} \mathrm{NaOH}$.

Organic carbon (OC) was determined by the method described by Sampaio et al. (2012), which used $\mathrm{Na}_{2} \mathrm{Cr}_{2} \mathrm{O}_{7}\left(0.667 \mathrm{~mol} \mathrm{~L}^{-1}\right)$ in sulfuric acid $\left(5 \mathrm{~mol} \mathrm{~L}^{-1}\right)$, and quantified the surplus $\mathrm{Na}_{2} \mathrm{Cr}_{2} \mathrm{O}_{7}$ that oxidized the organic carbon present in the sample by UV-V spectroscopy at $660 \mathrm{~nm}$ (Biospectro, model SP-22).

\section{Digestion of the samples}

Quantification of the metals cadmium, lead, copper, nickel and zinc $(\mathrm{Cd}, \mathrm{Pb}, \mathrm{Cu}, \mathrm{Cr}, \mathrm{Ni}$ and $\mathrm{Zn})$ was accomplished by digestion via chemical extractors $\left(\mathrm{HNO}_{3}+\mathrm{HCl}+\mathrm{H}_{2} \mathrm{O}_{2}\right)$, according to Method 3050B - EPA (1996), and quantified using the VARIAN Model 720-ES ICP-OES of the Laboratório de Fertilidade do Solo of the Universidade Federal do Paraná (UFPR), section Ciências Agrárias. The metals were quantified using a calibration curve constructed with a standard for each metal and expressed in milligrams per kilogram of soil $\left(\mathrm{mg} \mathrm{kg}^{-1}\right)$. The analyses where performed in triplicate and the results were expressed as means and standard deviations.

\section{Geoaccumulation Index (Igeo)}

The $I_{\text {geo }}$ was used to assess the degree of elemental pollution in the soils of the study areas (MULER, 1969; BRUIYAN et al., 2010). The Igeo is given by Equation 1:

$$
I_{\text {geo }}=\log _{2}\left(C_{n} / k B_{n}\right)
$$

(Equation 1)

where $C_{n}$ is the concentration of the heavy metal in the soil sample, $B_{n}$ is the geochemical background value of the heavy metal $(n)$ and $k=1.5$ is a correction factor for the background matrix introduced to explain possible differences in background values due to lithospheric effects. The geochemical background values were obtained from the data of MINEROPAR (2005).

The $I_{\text {geo }}$ of each metal was calculated and classified as follows: not contaminated $\left(I_{\text {geo }} \leq 0\right)$; not contaminated to moderately contaminated $\left(0<I_{\text {geo }} \leq 1\right)$; moderately contaminated $\left(1<I_{\text {geo }} \leq 2\right)$; moderately to heavily contaminated $\left(2<I_{\text {geo }} \leq 3\right)$; heavily contaminated $\left(3<I_{\text {geo }} \leq 4\right)$; heavily to extremely contaminated 
$\left(4<\right.$ Igeo $\left._{5} \leq 5\right)$; and extremely contaminated (Igeo $\left.\geq 5\right)$ (ZAHRA et al., 2014; WEl et al., 2015).

\section{Contamination Factor (CF)}

Soil has the capacity to record history and indicate the degree of pollution. The Contamination Factor (CF) is an index (Equation 2) expressed by dividing the concentration of each metal in the soil by a baseline or background value (Equation 2), being effective in pollution control over a period of time. The concentration of a given metal in an environment is controlled by various parameters, such as the nature of the substrate, physico-chemical conditions, which control the dissolution and precipitation of metals, and the proximity of polluted sites (NOBI et al., 2010; CHANDRASEKARAN et al., 2015; KARIM et al., 2015; WU et al., 2015).

$$
\mathrm{CF}=\mathrm{C}_{\text {heavy metal }} / \mathrm{C}_{\text {background }} \quad \text { (Equation 2) }
$$

Contamination levels can be classified, based on their intensities, on a scale of 1 to 6 ( $0=$ none, $1=$ none to moderate, $2=$ moderate, $3=$ moderate to strong, $4=$ strong, $5=$ strong to very strong, $6=$ very strong) (ZAHRA et al., 2014; CHANDRASEKARAN et al., 2015; WU et al., 2015). The background values adopted for each element were obtained from MINEROPAR (2005).

\section{Statistical analysis}

Statistical analyses were performed using the software ACTION ${ }^{\bullet}$ Version 2.9 (Statcamp, São Carlos, $\mathrm{SP})$. The values are reported as mean \pm standard deviation (SD) for each test. The Pearson correlation analysis was performed for the sampling points of $\mathrm{AR}$ and $\mathrm{CL}$ between the heavy metals and the elements $\mathrm{Ca}$ and $\mathrm{Mg}$.

\section{RESULTS AND DISCUSSION}

First, the soil was characterized by the fractions of sand, clay and silt (Table 1) using the data obtained and a textural triangle.

Table 1: Soil composition of PRF points of Araucaria (AR) and Colombo (CL).

\begin{tabular}{|c|c|c|c|}
\hline Sample & Sand / \% & Clay / \% & Silt / \% \\
\hline AR & $* 58,19 \pm 15,71$ & $* 0,84 \pm 0,55$ & $* 40,97 \pm 15,48$ \\
\hline Minimum & 24,70 & 0,38 & 18,78 \\
\hline Maximum & 79,28 & 2,20 & 73,10 \\
\hline $\mathrm{CL}$ & $* 48,09 \pm 16,82$ & $* 1,67 \pm 0,54$ & $* 50,25 \pm 16,63$ \\
\hline Minimum & 24,68 & 0,53 & 18,28 \\
\hline Maximum & 80,65 & 2,50 & 73,27 \\
\hline
\end{tabular}

* Results expressed as average \pm S.D. $(n=3)$

As shown in Table 1, there is variability in the textural composition between areas, reflecting an elevated heterogeneity, which is common in urban areas (ALLOWAY, 2004). The high standard deviation associated with proximate points reflects high variation in local mineralogical composition, suggesting an external input of material, which can thus contribute to heavy metal content and alter the physical and chemical characteristics of the soil.

In short, both areas have a predominance of sand in the soil surface $(0-20 \mathrm{~cm})$, with a texture characterized as franco-sandy, franco-silty or sandy-franco. The region of AR is predominately franco-sandy and sandy-franco, because of the large proportion of sand in the soil, while CL has, on average, higher levels 
of clay and silt, and is predominantly franco-silty. These physical characteristics impart properties to the soil such as drainage, cohesion, plasticity and presence of fillers, and has a direct relationship to the mobility of metals and nutrients, which is usually greater in sandy soils due to the absence of charged particles (HASHIM et al., 2011). Table 2 provides the levels of organic carbon (OC) and pH in aqueous medium and in aqueous medium of calcium chloride.

Table 2: Maximum, average and minimum values of Organic Carbon (CO), $\mathrm{pH}_{\mathrm{H} 2 \mathrm{O}}$ and $\mathrm{pH} \mathrm{CaCl}_{2}$ of sampling sites in Araucaria (AR) and Colombo (CL).

\begin{tabular}{|c|c|c|c|}
\hline Sample & $\mathrm{CO}\left(\mathrm{g} \mathrm{dm}^{-3}\right)$ & $\mathrm{pH}_{\mathrm{H} 2 \mathrm{O}}$ & $\mathrm{pH}_{\mathrm{CaCl} 2}$ \\
\hline$A R$ & $* 37,63 \pm 14,27$ & $* 5,05 \pm 0,55$ & $* 4,99 \pm 1,07$ \\
\hline Minimum & 16,03 & 4,17 & 3,62 \\
\hline Maximum & 61,72 & 6,33 & 6,65 \\
\hline $\mathrm{CL}$ & $* 45,53 \pm 13,26$ & $* 6,22 \pm 0,56$ & $* 6,14 \pm 0,57$ \\
\hline Minimum & 24,83 & 5,12 & 4,57 \\
\hline Maximum & 71,55 & 6,81 & 6,58 \\
\hline
\end{tabular}

* Results expressed as average \pm S.D. $(n=3)$

The region of $\mathrm{CL}$ has higher $\mathrm{OC}$ content than that of $\mathrm{AR}$. Organic carbon in the soil influences the adsorption of heavy metals, probably due to the cation exchange capacity (CEC) (ROMIC et al., 2003). The surface electrical charge of $O C$ is a major contributor to the CEC of soils due to their ease of deprotonation and their high specific surface area that can reach $800-900 \mathrm{~m}^{2} \mathrm{~g}^{-1}$ (ALLOWAY, 1995; COSTA et al., 2006; SILVA et al., 2006).

Soil $\mathrm{pH}$ reflects a complex set of reactions in the soil-solution system, and is useful for clarifying the state of bases and the solubility of micronutrients (MEHLICH, 1948). Soil pH can also affect the availability of heavy metals (MEHLICH, 1948). According to Alloway (1995), heavy metals are more mobile under acidic conditions because with the decrease in $\mathrm{pH}$ the $\mathrm{H}^{+}$ions compete with the heavy metals for exchange sites, and their consequent increase reduces their availability because the negative charges caused by deprotonation of the soil components tend to be balanced by the metals.

The $\mathrm{pH}$ of the soil of the analyzed points was acidic, with values below 7.0. The $\mathrm{pH}$ in water indicates active acidity, but does not include the weak acids contained in the soil. The determination of soil pH with $\mathrm{CaCl}_{2}$ produces values lower than those measured in water due to the inclusion of the weak acids in the soil (CAMARGO et al., 2009). The pH of soil in aqueous solution varied between 4.17 and 6.33 in AR and between 5.12 and 6.81 in $\mathrm{CL}$, whereas in calcium chloride solution it varied between 3.62 and 6.65 in $A R$ and between 4.57 and 6.58 in $\mathrm{CL}$.

Table 3: Maximum, average and minimum values of Aluminum, Calcium and Magnesium of sampling sites in Araucaria (AR) and Colombo (CL).

\begin{tabular}{|c|c|c|c|}
\hline Sample & $\begin{array}{l}\mathrm{Al}^{3+} \\
\left(\mathrm{mol} \mathrm{kg}^{-1}\right)\end{array}$ & $\begin{array}{l}\mathrm{Ca}^{2+} \\
\left(\mathrm{mg} \mathrm{kg}^{-1}\right)\end{array}$ & $\begin{array}{l}\mathrm{Mg}^{2+} \\
\left(\mathrm{mg} \mathrm{kg}^{-1}\right)\end{array}$ \\
\hline AR & $* 0,33 \pm 0,30$ & $* 2218,50 \pm 1095,27$ & $* 741,75 \pm 411,28$ \\
\hline Minimum & 0,03 & 56,25 & 22,50 \\
\hline Maximum & 0,90 & 3903,75 & 1496,25 \\
\hline $\mathrm{CL}$ & $* 0,21 \pm 0,17$ & 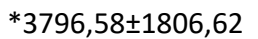 & *1127,96 $\pm 446,36$ \\
\hline Minimum & 0,1 & 1012,50 & 416,25 \\
\hline Maximum & 0,5 & 7346,25 & 1901,25 \\
\hline
\end{tabular}

* Results expressed as average \pm S.D. $(n=3)$

The physical and chemical parameters of the soil influence the adsorption of metals and nutrients. 
Soil $\mathrm{pH}$, for example, facilitates the mobility and increases the toxicity of some metals. Soil OC has the ability to adsorb or complex metals with clay, and its presence in the soil can moderate the mobility of metal to deeper layers. Exchangeable aluminum $\left(\mathrm{Al}^{3+}\right)$, calcium $\left(\mathrm{Ca}^{2+}\right)$ and magnesium $\left(\mathrm{Mg}^{2+}\right)$ were measured and are shown in Table 3.

The levels of $\mathrm{Ca}^{+2}$ and $\mathrm{Mg}^{+2}$ were higher in $\mathrm{CL}$. The inter relationship between $\mathrm{Ca}^{+2}$ and $\mathrm{Mg}^{+2}$ in plant nutrition is related to their chemical properties, such as the degree of hydration and mobility, so that there is competition for the adsorption sites in the soil. As a result, the presence of one can hinder the adsorbtion and absorbtion of the other (ORLANDO FILHO et al., 1996).

The region of $\mathrm{AR}$ had higher levels of $\mathrm{Al}^{+}$, along with a more acidic soil $\mathrm{pH}$, compared to $\mathrm{CL}$. In acidic soils, toxic aluminum can be present, which is harmful to plants by influencing the development of their root system. However, above pH 5.5 toxic aluminum is absent due to its precipitation in the form of aluminum oxide (BOHNEN, 1995; ECHART et al., 2001).

Metals were quantified using ICP-OES, and the results compared with the Resolution CONAMA 420 (2009), the federal rule which defines three concentration values for metals in soil. Prevention Value (PV) refers to the concentration limit of a given substance in the soil; Quality Reference Value (QRV) refers to the concentration of a given substance that defines the natural quality of the soil; and Investigation Value, which is the concentration of a given substance in the soil or groundwater above which there are potential direct and/or indirect risks. Quantification of the metals $\mathrm{Cr}, \mathrm{Cu}, \mathrm{Ni}, \mathrm{Pb}$ and $\mathrm{Zn}$ in samples from $\mathrm{AR}$ and $\mathrm{CL}$ are presented in Figure 2, along with their PVs and IVs.

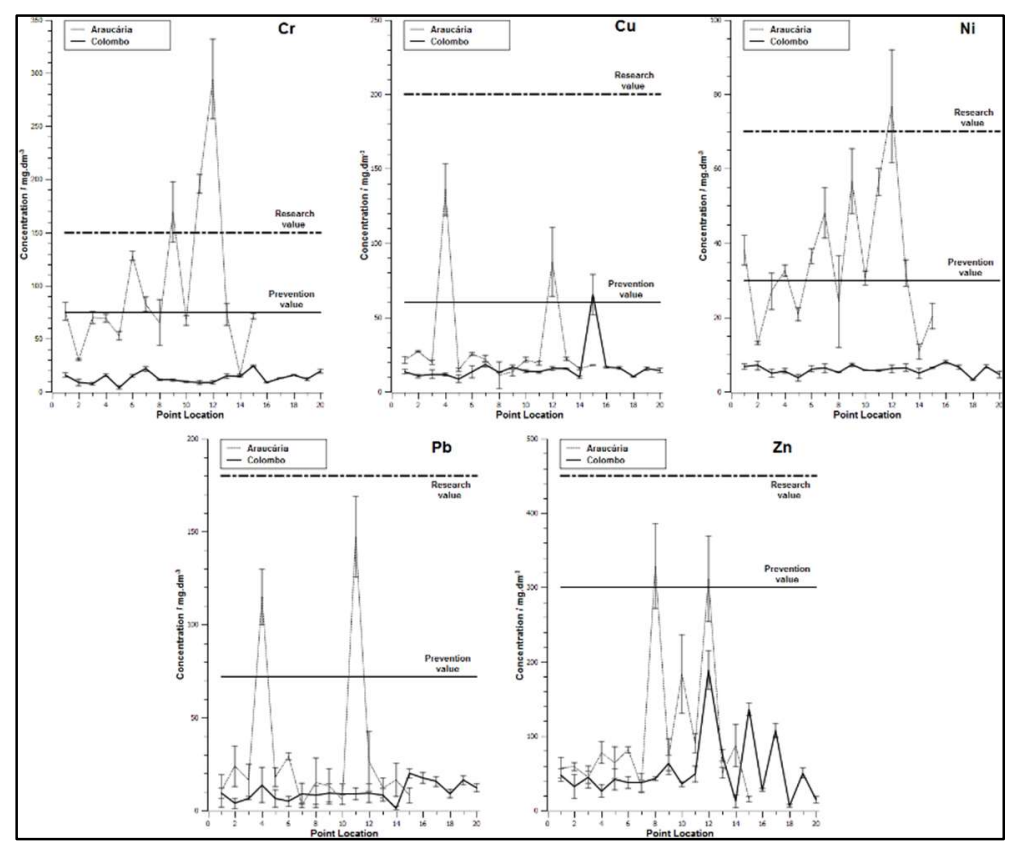

Fig. 2: Concentration of $\mathrm{Cr}, \mathrm{Cu}, \mathrm{Ni}, \mathrm{Pb}$ and $\mathrm{Zn}$ in soil samples in Araucaria (AR) and Colombo (CL).

Environmental pollution with heavy metals is a major concern on a global scale and the risk associated with exposure to heavy metals in food and water is considered a threat to human health (SAEIDEHKORDI et al., 2011). As shown in Figure 2, there is a clear change in the heavy metal content in the soils, as was also the case for textural composition. These characteristics can be due to various factors, such as OC, 
$\mathrm{pH}$ of the soil, textural composition and the direct contact of vehicles with the soil (COVELO et al., 2007b, a; KASHEM et al., 2007).

Through the results regarding metals in the present study, the environments can be classified according Resolution CONAMA 420 (2009). The region AR exhibited higher content of heavy metals, especially $\mathrm{Ni}$ and $\mathrm{Cr}$, which at some sampling points surpassed IV. For the metals $\mathrm{Cu}, \mathrm{Pb}$ and $\mathrm{Zn}$, the values exceeded PV at some sampling points. Therefore, the area AR is classified in Class 4 according to the Resolution CONAMA 420 (2009). The concentrations of the analyzed metals ( $\mathrm{Ni}, \mathrm{Cr}, \mathrm{Zn}$ and $\mathrm{Pb}$ ) at region $\mathrm{CL}$ were below PV, with the exception of the element $\mathrm{Cu}$, and so it was classified in Class 3.

After soil classification, and in accordance with the provision of Art. 20 of Resolution CONAMA 420 (2009), procedures for contamination prevention and quality control of the soil should be adopted. In the case of $\mathrm{CL}$, this resolution requires the identification of the potential source of contamination, assessment of the natural occurrence of the substance, control of the source of contamination and monitoring of soil and groundwater quality.

The region AR requires actions established in Chapter IV of Resolution CONAMA 420 (2009), related to the management of contaminated areas, and should contain procedures and actions aimed at meeting the following goals of the provisions of Art. 22: I - eliminate the hazard or reduce risk to human health; II eliminate or minimize the risks to the environment; III - prevent damage to other assets to be protected; IV - prevent damage to public well-being while performing actions of rehabilitation; and $\mathrm{V}$ - enable the declared or future use of the area, noting the planning of land use and occupation.

In order to assess the level of contamination and possible anthropogenic impacts on the soil, Igeo and CF were estimated for the heavy metals evaluated in this study. The values of $I_{\text {geo }}$ for the heavy metals from soil samples of the vehicle deposits are shown in Table 4.

Table 4: Geoaccumulation index (Igeo) of heavy metals in soil samples in a deposit of PRF in Araucaria (AR) and Colombo (CL).

\begin{tabular}{|c|c|c|c|c|c|}
\hline Sample & $\mathrm{Cr}$ & $\mathrm{Cu}$ & $\mathrm{Ni}$ & $\mathrm{Pb}$ & $\mathrm{Zn}$ \\
\hline$A R$ & $*_{-0,26 \pm 0,54}$ & $*-1,90 \pm 0,97$ & $*_{-4,08 \pm 2,43}$ & $*-1,06 \pm 1,45$ & $*-1,54 \pm 0,81$ \\
\hline Minimum & $-1,87$ & $-2,99$ & $-8,98$ & $-5,27$ & $-3,09$ \\
\hline Maximum & 0,43 & 0,62 & 0,03 & 0,48 & $-0,26$ \\
\hline $\mathrm{CL}$ & $*-3,19 \pm 0,61$ & $*-2,61 \pm 0,59$ & $*-2,69 \pm 0,32$ & $*-2,51 \pm 0,90$ & $*-1,18 \pm 1,15$ \\
\hline Minimum & $-4,85$ & $-3,36$ & $-3,55$ & $-5,35$ & $-3,92$ \\
\hline Maximum & $-2,17$ & $-0,44$ & $-2,23$ & $-1,29$ & 1,04 \\
\hline
\end{tabular}

* Results expressed as average \pm S.D. $(n=3)$

The sampling points of $A R$ and $C L$ have different $I_{\text {geo }}$ values. Table 4 provides a broad view accompanied with the minimum and maximum points, which suggests an environment with high deviation concentration of these metals in various parts of the studied area. The average values of $I_{\text {geo }}$ in AR are all negative, indicating no external input, but the maximum points indicate an evident contribution of nickel, chromium, lead and copper for some points. For the sampling points of $\mathrm{CL}$, all values of $\mathrm{I}_{\text {geo }}$ are negative, including the maximums, suggesting that the soil of that region is not receiving an external input of metals.

The input of heavy metals in the vehicle depositories, and their importance to the environment, are evident. The data demonstrated that the analyzed metals are randomly distributed among the soil surface. 
These oscillations in the concentration of metals are due to two factors: (i) the local textural composition of the soil; and (ii) the spatial distribution of the vehicles on the soil. The Contamination Factor (CF) was calculated to elucidate the level of contamination and possible anthropogenic impacts on the soil, supplementing the results obtained previously. The CF values are shown in Table 5.

Table 5: Contamination factor (CF) of heavy metals in soil samples in a deposit of PRF in Araucaria (AR) and Colombo (CL).

\begin{tabular}{|c|c|c|c|c|c|}
\hline Sample & $\mathrm{Cr}$ & $\mathrm{Cu}$ & $\mathrm{Ni}$ & $\mathrm{Pb}$ & $\mathrm{Zn}$ \\
\hline$A R$ & $* 0,27 \pm 0,42$ & $* 0,25 \pm 0,59$ & $* 0,35 \pm 0,56$ & $* 0,38 \pm 0,91$ & $* 0,33 \pm 0,49$ \\
\hline Minimum & 0,00 & 0,00 & 0,00 & 0,00 & 0,00 \\
\hline Maximum & 1,03 & 2,30 & 1,53 & 3,55 & 1,27 \\
\hline $\mathrm{CL}$ & $* 0,06 \pm 0,10$ & $* 0,07 \pm 0,11$ & $* 0,08 \pm 0,12$ & $* 0,08 \pm 0,13$ & $* 0,22 \pm 0,31$ \\
\hline Minimum & 0,00 & 0,00 & 0,00 & 0,00 & 0,00 \\
\hline Maximum & 0,30 & 0,31 & 0,28 & 0,42 & 0,78 \\
\hline
\end{tabular}

* Results expressed as average \pm S.D. $(n=3)$

The results of Table 5 clearly show that the sampling points in AR have greater import than the points of $\mathrm{CL}$. The elements $\mathrm{Cr}, \mathrm{Zn}$ and $\mathrm{Ni}$ showed low contamination, with maximum values of $1.03,1.27$ and 1.53, respectively. The elements $\mathrm{Pb}$ and $\mathrm{Cu}$ did not have significant average values in $\mathrm{AR}$, however, their maximum values were 3.55 and 2.30 , respectively, indicating mild levels of contamination.

The sampling points of region $\mathrm{CL}$, as with $\mathrm{I}_{\mathrm{geo}}$, showed a low level of contamination, with the exception of the element $\mathrm{Zn}$, which had a maximum CF of 0.78 , but an average of 0.22 . Tables 6 and 7 show the correlation among the heavy metals in the soil surface of AR and CL respectively.

Table 6: Pearson Correlation Matrix and their p-values for metal points of Araucaria.

\begin{tabular}{|c|c|c|c|c|c|c|c|}
\hline Metals & $\mathrm{Cr}$ & $\mathrm{Cu}$ & $\mathrm{Ni}$ & $\mathrm{Pb}$ & $\mathrm{Zn}$ & $\mathrm{Ca}$ & $\mathrm{Mg}$ \\
\hline $\mathrm{Cr}$ & 1,000 & I 0,288 & ' 0,930 & I 0,299 & 10,426 & I 0,454 & 0,728 \\
\hline $\mathrm{Cu}$ & " 0,298 & 1,000 & ' 0,298 & ' 0,481 & ' 0,200 & ' 0,129 & '0,096 \\
\hline $\mathrm{Ni}$ & " 0,000 & " 0,281 & 1,000 & ' 0,260 & ' 0,322 & ' 0,515 & ' 0,762 \\
\hline $\mathrm{Pb}$ & " 0,279 & "0,069 & "0,349 & 1,000 & I $-0,033$ & ' 0,239 & ' 0,286 \\
\hline $\mathrm{Zn}$ & " 0,113 & "0,476 & " 0,242 & " 0,908 & 1,000 & ' 0,219 & ' 0,330 \\
\hline $\mathrm{Ca}$ & " 0,089 & "0,648 & " 0,050 & " 0,391 & "0,434 & 1,000 & ' 0,797 \\
\hline $\mathrm{Mg}$ & " 0,002 & "0,734 & " 0,001 & " 0,302 & "0,230 & " 0,000 & 1,000 \\
\hline
\end{tabular}

I Pearson Correlation Matrix; II Matrix of p-values.

According to the Pearson correlations shown in Table 6, the elements $\mathrm{Ni}$ and $\mathrm{Mg}$ were significantly correlated with the element $\mathrm{Cr}$, with values of 0.93 and 0.73 , respectively, both with $\mathrm{p}$-values below the adopted 5\%. A significant positive correlation between the elements $\mathrm{Ni}$ and $\mathrm{Cr}$ was found in the study of CAI et al. (2015), with a value of 0.81 . These elevated values suggest that the metals $\mathrm{Cr}, \mathrm{Ni}$ and $\mathrm{Mg}$ were probably derived from the same source. The elements $\mathrm{Ni}$ and $\mathrm{Ca}$ are directly correlated with the element $\mathrm{Mg}$, with values of 0.76 and 0.80 , respectively, and with p-values below $5 \%$. Chandrasekaran et al. (2015) found a significant positive correlation between $\mathrm{Ca}$ and $\mathrm{Mg}$, with a value of 0.63 .

Table 7 provides the Pearson correlations for the points analyzed in CL. The element $\mathrm{Cr}$ had a direct correlation of 0.59 with the element $\mathrm{Cu}$, and this with elements $\mathrm{Pb}$ and $\mathrm{Zn}$, with values of 0.62 and 0.53 , respectively. The elements $\mathrm{Ca}$ and $\mathrm{Mg}$ were positively correlated with 0.88 . Results of a study by Chandrasekaran et al. (2015) found 0.63 . The element $\mathrm{Ni}$ was found to be positively correlated with the elements $\mathrm{Ca}$ and $\mathrm{Mg}$, with values of 0.66 and 0.65 , respectively. A positive correlation was likewise observed 
between the elements $\mathrm{Zn}$ and $\mathrm{Ca}$ at 0.55 .

Table 7: Pearson Correlation Matrix and their $\mathrm{p}$-values for metal points of Colombo.

\begin{tabular}{|c|c|c|c|c|c|c|c|}
\hline Metais & $\mathrm{Cr}$ & $\mathrm{Cu}$ & $\mathrm{Ni}$ & $\mathrm{Pb}$ & $\mathrm{Zn}$ & $\mathrm{Ca}$ & $\mathrm{Mg}$ \\
\hline $\mathrm{Cr}$ & 1,000 & '0,585 & '0,051 & 10,353 & I 0,041 & $1-0,272$ & I $-0,130$ \\
\hline $\mathrm{Cu}$ & " 0,009 & 1,000 & ' 0,242 & '0,622 & ' 0,528 & '0,098 & ' 0,203 \\
\hline $\mathrm{Ni}$ & " 0,834 & " 0,318 & 1,000 & ' 0,341 & ' 0,285 & ' 0,657 & ' 0,652 \\
\hline $\mathrm{Pb}$ & " 0,139 & "0,005 & " 0,154 & 1,000 & ' 0,283 & ' 0,247 & ' 0,474 \\
\hline $\mathrm{Zn}$ & " 0,868 & $" 0,020$ & "0,236 & " 0,241 & 1,000 & '0,551 & ' 0,419 \\
\hline $\mathrm{Ca}$ & $" 0,260$ & " 0,691 & "0,002 & "0,309 & " 0,015 & 1,000 & 0,878 \\
\hline $\mathrm{Mg}$ & "0,597 & "0,405 & " 0,003 & " 0,040 & $" 0,074$ & " 0,000 & 1,000 \\
\hline
\end{tabular}

"Pearson Correlation Matrix; " Matrix of p-values.

The results of the present study suggest that although the two regions differed, the metals $(\mathrm{Cr}, \mathrm{Cu}$, $\mathrm{Ni}, \mathrm{Pb}, \mathrm{Zn}$ ) were probably derived from the same source and of anthropic origin, because these metals are present in the structure and pigments of vehicles and as constituents of lubricants.

The soil of the sampling sites was not uniform, with traces of upturned soil, with sand, rocks, earth and gravel. It is worth noting that in both sampling sites the vehicles were close to the ground and there were puddles stained with oil, thus being able to infer the results and justify the standard deviation of the data.

\section{CONCLUSIONS}

In conclusion, the present study found high concentrations of $\mathrm{Cu}, \mathrm{Cr}, \mathrm{Ni}, \mathrm{Pb}$ and $\mathrm{Zn}$ in the vehicle depository of AR, which were higher than the levels permitted by Resolution CONAMA 420. The Pearson correlation analysis showed that the analyzed metals likely have anthropic origins in both AR and CL. Because of the contamination of the soil in AR, a better evaluation of the sources of heavy metals is highly recommended and that monitoring of soil and water be performed. In the vehicle depository of $\mathrm{CL}$, the low concentration of the heavy metals, combined with higher clay and organic carbon content and higher $\mathrm{pH}$ than $A R$, favor the adsorption of metals.

Clearly, AR deserves greater attention for risk of contamination because in addition to having an acidic $\mathrm{pH}$, which favors the solubilization of metals, it possesses lower clay and organic carbon content, both of which are attributes that facilitate the processes of percolation and leaching of these metals. In general, the results of this study suggests that there is a need for special attention to vehicle storage areas that are not paved/sealed, since these are potential sources of soil and water degradation.

ACKNOWLEDGMENTS: We would like to thank UTFPR Campus Curitiba for the laboratory structure, to the Department of Soil and Agricultural Engineering of UFPR - Plant Nutrition Laboratory, Chemical and Fertility of Soil Laboratory (DSEA/SCA/UFPR) and to the Fundação Araucária for the scholarship and opportunity of participation in this project.

\section{REFERENCES}

AHMED, M. K.; BAKI, M. A.; ISLAM, M. S.; KUNDU, G. K.; HABIBULLAH-AI-MAMUN, M.; SARKAR, S. K.; HOSSAIN, M. $M$.. Human health risk assessment of heavy metals in tropical fish and shellfish collected from the river Buriganga,
Bangladesh. Environmental Science and Pollution Research, v.22, n.20, p.15880-15890, 2015. DOI:

http://dx.doi.org/10.1007/s11356-015-4813-z 
ALLOWAY, B. J.. Heavy metals in soils. 2 ed. London: Blackie Academic, 1995.

ALLOWAY, B. J.. Contamination of soils in domestic gardens and allotments: a brief overview. Land Contamination \& Reclamation, v.12, n.3, p.179-187, 2004. DOI: http://dx.doi.org/10.2462/09670513.658

BRUIYAN, M. A.; PARVEZ, L.; ISLAM, M.; DAMPARE, S. B.; SUZUKI, S.. Heavy metal pollution of coal mine-affected agricultural soils in the northern part of Bangladesh. Journal of hazardous materials, v.173, p.384-392, 2010. DOI: http://dx.doi.org/10.1016/j.jhazmat.2009.08.085

BOHNEN, H.. Acidez e calagem. IN: GIANELLO, C.; BISSANI, C. A.; TEDESCO, M. J.. Princípios de fertilidade de solo. Porto Alegre: UFRGS, 1995, p.51-76.

BRANDÃO, C. J.. Guia nacional de coleta e preservação de amostras: água, sedimento, comunidades aquáticas e efluentes líquidas. São Paulo; CETESB; Brasília: ANA, 2011.

CAI, L.; XU, Z.; BAO, P.; HE, M.; DOU, L.; CHEN, L.; ZHOU, Y.; $\mathrm{ZHU}, \mathrm{Y}$.. Multivariate and geostatistical analyses of the spatial distribution and source of arsenic and heavy metals in the agricultural soils in Shunde, Southeast China. Journal of Geochemical Exploration, v.148, p.189-195, 2015. DOI: http://dx.doi.org/10.1016/j.gexplo.2014.09.010

CAMARGO, O. A.; MONIZ, A. C.; JORGE, J. A.; VALADARES, J. M. A. S.. Métodos de Análise Química, Mineralógica e Física de Solos do Instituto Agronômico de Campinas. Campinas: Instituto Agronômico, 2009.

CHANDRASEKARAN, A.; RAVISANKAR, R.; HARIKRISHNAN, N.; SATAPATHY, K. K.; PRASAD, M. V. R.; KANAGASABAPATHY, K. V.. Multivariate statistical analysis of heavy metal concentration in soils of Yelagiri Hills, Tamilnadu, India Spectroscopical approach. Spectrochimica Acta Part aMolecular and Biomolecular Spectroscopy, v.137, p.589600, 2015. DOI: http://dx.doi.org/10.1016/j.saa.2014.08.093

COSTA, C. N.; MEURER, E. J.; BISSANI, C. A.; SELBACH, P. A.. Contaminantes e poluentes do solo e do ambiente. In: MEURER, J. E.. Fundamentos de química do solo. 3 ed. Porto Alegre: Evangraf, 2011. p. 213-250.

COVELO, E. F.; VEGA, F. A.; ANDRADE, M. L.. Simultaneous sorption and desorption of $\mathrm{Cd}, \mathrm{Cr}, \mathrm{Cu}, \mathrm{Ni}, \mathrm{Pb}$, and $\mathrm{Zn}$ in acid soils - II. Soil ranking and influence of soil characteristics. Journal of Hazardous Materials, v.147, p.862-870, 2007a. DOI: http://dx.doi.org/10.1016/j.jhazmat.2007.01.108

COVELO, E. F.; VEGA, F. A.; ANDRADE, M. L.. Simultaneous sorption and desorption of $\mathrm{Cd}, \mathrm{Cr}, \mathrm{Cu}, \mathrm{Ni}, \mathrm{Pb}$, and $\mathrm{Zn}$ in acid soils I. selectivity sequences. Journal of Hazardous

Materials, v.147, p.852-861, 2007b. DOI:

http://dx.doi.org/10.1016/j.jhazmat.2007.01.123

DUARTE, B.; DELGADO, M.; CACADOR, I.. The role of citric acid in cadmium and nickel uptake and translocation, in Halimione portulacoides. Chemosphere, v.69, p.836-840, 2007. DOI:

http://dx.doi.org/10.1016/i.chemosphere.2007.05.007

DURUIBE, J. O.; OGWUEGBU, M. O. C.; EGWURUGWU, J. N.. Heavy metal pollution and human biotoxic effects.
International Journal of Physical Sciences, v.2, p.112-118, 2007.

ECHART, C. L.; CAVALLI-MOLINA, S.. Fitotoxicidade do alumínio: efeitos, mecanismo de tolerância e seu controle genético. Ciência Rural, v.31, p.531-541, 2001. DOI: http://dx.doi.org/10.1590/S0103-84782001000300030

EMBRAPA. Manual de métodos de análise de solo. 2 ed. Rio de Janeiro, 1997.

EPA. Method 3050B: Acid Digestion of Sediments, Sludges, and Soils. Washington: EPA, 1996.

HASHIM, M. A.; MUKHOPADHYAY, S.; SAHU, J. N.; SENGUPTA, B.. Remediation technologies for heavy metal contaminated groundwater. Journal of Environmental Management, v.92, p.2355-2388, 2011. DOI: http://dx.doi.org/10.1016/j.jenvman.2011.06.009

HONG, K. J.; TOKUNAGA, S.; KAJIUCHI, T.. Evaluation of remediation process with plant-derived biosurfactant for recovery of heavy metals from contaminated soils. Chemosphere, v.49, p.379-387, 2002. DOI: http://dx.doi.org/10.1016/S0045-6535(02)00321-1

IKEDA, M.; ZHANG, Z. W.; SHIMBO, S.; WATANABE, T.; NAKATSUKA, H.; MOON, C. S.; MATSUDA-INOGUCHI, N.; HIGASHIKAWA, K.. Urban population exposure to lead and cadmium in east and south-east Asia. Science of the Total Environment, v.249, p.373-384, 2000. DOI: http://dx.doi.org/10.1016/S0048-9697(99)00527-6

ISLAM, M. S.; AHMED, M. K.; HABIBULLAH-AL-MAMUN, M.; RAKNUZZAMAN, M.. The concentration, source and potential human health risk of heavy metals in the commonly consumed foods in Bangladesh. Ecotoxicology and Environmental Safety, v.122, p.462-469, 2015. DOI: http://dx.doi.org/10.1016/j.ecoenv.2015.09.022

KARIM, Z.; QURESHI, B. A. L.; MUMTAZ, M.. Geochemical baseline determination and pollution assessment of heavy metals in urban soils of Karachi, Pakistan. Ecological Indicators, v.48, p.358-364, 2015. DOI: http://dx.doi.org/10.1016/j.ecolind.2014.08.032

KASHEM, M. A.; SINGH, B. R.; KAWAI, S.. Mobility and distribution of cadmium, nickel and zinc in contaminated soil profiles from Bangladesh. Nutrient Cycling in Agroecosystems, v.77, p.187-198, 2007. DOI: http://dx.doi.org/10.1007/s10705-006-9056-4

MEHLICH, A.. Determination of cation exchange and anion exchange properties of soils. Soil Science, v.66, p.429-445, 1948. DOI: http://dx.doi.org/10.1097/00010694-19481200000004

MINEROPAR. Levantamento geoquímico multielementar do estado do Paraná: Geoquímica de solo. Belo Horizonte, 2005.

MULER, G.. Index of geoaccumulation in sediments of the Rhine River. GeoJournal, v.2, p.108-118, 1969.

NOBI, E. P.; DILIPAN, E.; THANGARADJOU, T.; SIVAKUMAR, K.; KANNAN, L.. Geochemical and geo-statistical assessment of heavy metal concentration in the sediments of different 
coastal ecosystems of Andaman Islands, India. Estuarine Coastal and Shelf Science, v.87, p.253-264, 2010. DOI: http://dx.doi.org/10.1016/i.ecss.2009.12.019

ORLANDO FILHO, J. O.; BITTENCOURT, V. C.; CARMELLO, Q. A. C.; BEAUCLAIR, E. G. F.. Relações K, Ca e Mg de solo areia quartzosa e produtividade da cana-de-açúcar. Stab. Açucar, Álcool e Subprodutos, Piracicaba, v.14, p.13-17, 1996.

PEREIRA, A. A.; BORGES, J. D.; LEANDRO, W. M.. Heavy metals and micronutrients in soil and in leaves of Brachiaria decumbens on the margins of highways. Bioscience Journal, v.26, p.347-357, 2010.

POURANG, N.; NOORI, A. S.. Heavy metals contamination in soil, surface water and groundwater of an agricultural area adjacent to Tehran oil refinery, Iran. International Journal of Environmental Research, v.8, p.871-886, 2014.

PRADHAN, J. K.; KUMAR, S.. Informal e-waste recycling: environmental risk assessment of heavy metal contamination in Mandoli industrial area, Delhi, India. Environmental Science and Pollution Research, v.21, p.7913-7928, 2014. DOI: http://dx.doi.org/10.1007/s11356014-2713-2

RAHMAN, M. A.; RAHMAN, M. M.; REICHMAN, S. M.; LIM, R. P.; NAIDU, R.. Heavy metals in Australian grown and imported rice and vegetables on sale in Australia: Health hazard. Ecotoxicology and Environmental Safety, v.100, p.53-60, 2014. DOI:

http://dx.doi.org/10.1016/j.ecoenv.2013.11.024

BRASIL. Resolução CONAMA 420. Dispõe sobre critérios e valores orientadores de qualidade do solo quanto à presença de substâncias químicas e estabelece diretrizes para o gerenciamento ambiental de áreas contaminadas por essas substâncias em decorrência de atividades antrópicas. Brasília: CONAMA, 2009.

ROMIC, M.; ROMIC, D.. Heavy metals distribution in agricultural topsoils in urban area. Environmental Geology, v.43, p.795-805, 2003. DOI:

http://dx.doi.org/10.1007/s00254-002-0694-9

SAEI-DEHKORDI, S. S.; FALLAH, A. A.. Determination of copper, lead, cadmium and zinc content in commercially valuable fish species from the Persian Gulf using derivative potentiometric stripping analysis. Microchemical Journal, v.98, p.156-162, 2011. DOI:

http://dx.doi.org/10.1016/j.microc.2011.01.001

SAMPAIO, T. F.; FERNANDES, D. M.; GUERRINI, I. A.; BOGIANI, J. C.; BACKES, C.. Comparison between methods of organic matter determination in soil samples based on volume or mass. Revista Brasileira De Ciencia Do Solo, v.36, p.517-523, 2012. DOI: http://dx.doi.org/10.1590/S0100$\underline{06832012000200021}$

SERRANO, S.; GARRIDO, F.; CAMPBELL, C. G.; GARCIAGONZALEZ, M. T.. Competitive sorption of cadmium and lead in acid soils of Central Spain. Geoderma, v.124, p.91-104, 2005. DOI:

http://dx.doi.org/10.1016/j.geoderma.2004.04.002

SHUMAN, L. M.. Effect of organic waste amendments on cadmium and lead in soil fractions of two soils.

Communications in Soil Science and Plant Analysis, v.29, p.2939-2952, 1998. DOI:

http://dx.doi.org/10.1080/00103629809370167

SILVA, L. S.; CAMARGO, F. A. O.; CERETTA, C. A.. Composição da fase sólida orgânica do solo. In: MEURER, E. J..

Fundamentos de química do solo. 3 ed. Porto Alegre: Evangraf, 2006, p.63-90.

SINGH, P.; CAMEOTRA, S. S.. Enhancement of metal bioremediation by use of microbial surfactants. Biochemical and Biophysical Research Communications, v.319, p.291297, 2004. DOI:

http://dx.doi.org/10.1016/j.bbrc.2004.04.155

WEI, X.; GAO, B.; WANG, P.; ZHOU, H.; LU, J.. Pollution characteristics and health risk assessment of heavy metals in street dusts from different functional areas in Beijing, China. Ecotoxicology and Environmental Safety, v.112, p.186-192, 2015. DOI: http://dx.doi.org/10.1016/j.ecoenv.2014.11.005

WU, C.; LUO, Y.; DENG, S.; TENG, Y.; SONG, J.. Spatial characteristics of cadmium in topsoils in a typical e-waste recycling area in southeast China and its potential threat to shallow groundwater. Science of the Total Environment, v.472, p.556-561, 2014. DOI: http://dx.doi.org/10.1016/i.scitotenv.2013.11.084

WU, S.; PENG, S.; ZHANG, X.; WU, D.; LUO, W.; ZHANG, T.; ZHOU, S.; YANG, G.; WAN, H.; WU, L.. Levels and health risk assessments of heavy metals in urban soils in Dongguan, China. Journal of Geochemical Exploration, v.148, p.71-78, 2015. DOI: http://dx.doi.org/10.1016/j.gexplo.2014.08.009

ZAHRA, A.; HASHMI, M. Z.; MALIK, R. N.; AHMED, Z.. Enrichment and geo-accumulation of heavy metals and risk assessment of sediments of the Kurang Nallah-Feeding tributary of the Rawal Lake Reservoir, Pakistan. Science of the Total Environment, v.470, p.925-933, 2014. DOI: http://dx.doi.org/10.1016/j.scitotenv.2013.10.017

ZEITOUNI, C. D. F.; BERTON, R. S.; ABREU, C. A. Phytoextraction of cadmium and zinc from an oxisol contaminated with heavy metals. Bragantia, v.66, p.649657, 2007. DOI: http://dx.doi.org/10.1590/S0006$\underline{87052007000400015}$

A CBPC - Companhia Brasileira de Produção Científica (CNPJ: 11.221.422/0001-03) detém os direitos materiais desta publicação. Os direitos referem-se à publicação do trabalho em qualquer parte do mundo, incluindo os direitos às renovações, expansões e disseminações da contribuição, bem como outros direitos subsidiários. Todos os trabalhos publicados eletronicamente poderão posteriormente ser publicados em coletâneas impressas sob coordenação da Sustenere Publishing, da Companhia Brasileira de Produção Científica e seus parceiros autorizados. Os (as) autores (as) preservam os direitos autorais, mas não têm permissão para a publicação da contribuição em outro meio, impresso ou digital, em português ou em tradução. 